DOI https://doi.org/10.32405/2522-9931-9(38)-25-38

Удк 159.9.923

Viktoriia Overchuk,

candidate of Psychological Sciences,

docent, associate professor of the department of Psychology+

Vasyl' Stus Donetsk National University.

Vinnytsia, Ukraine

ORCID iD: https://orcid.org/0000-0002-7744-9346

vik.over030506@gmail.com

\title{
STIGMATIZATION OF PEOPLE WITH DISABILITY AS A PSYCHOLOGICAL BARRIER TOWARDS INTEGRATION TO SOCIAL LIFE
}

Annotation. Today, for Ukraine the problem of stigmatizing people with certain physical health disorders is actual. The implementation of social programs, actions and initiatives direct to the comprehensive rehabilitation of people with certain physical health disorders and realization their potential, despite all other factors; it is significantly slowed down by the fact that there is a set of persistent negative stereotypes in Ukrainian society regarding such people. Stigmatization of people with disability as a social group is becoming increasingly significant socio-cultural phenomenon. At the same time, the mechanisms of stigmatization are also manifested at the level of self-identification. People with disability may have at least three stigma strategies: the acceptance, speculation of illness and resistance. Particularly painful this question is for those with disability who strive for full value working life and professional realization. Stigmatization is quite close to discrimination. In addition, the causes of the problem are not only physical defects of people with disability. First, there is a high level of corruption in Ukraine and there are people who have made a disability for money. Certainly, after that, the society will be sceptical and suspicious for all people with disability, who do not have the physical manifestations of disability. Discrimination can be manifested in various forms when hiring and in the process of employment, on a daily attitude towards the person with the disability.

The problem of discrimination and stigmatization of people with disability remains acute both in Ukraine and in other countries of the world. However, it is obvious that the formal prohibition of discrimination at the state level does not eliminate this problem. Particularly painful is the question for those people with disability who see a fulfilling working life and professional realization. 
To removal the problem of discrimination and stigmatization, the scientists suggest work in two ways: to take action with those who are stigmatized and discriminated and with those who stigmatizes and discriminates, which requires different methods of solving the problem. Working with people with disability should help them to take an active life position, and this should be supported by appropriate rehabilitation, training, counselling and infrastructure arrangements. In turn, the working with others should be directed to developing a conscious vision of the problems of people with disability, understanding and tolerance.

Thus, one of the important measures in the medium and long term is to carry out the scientific research on various topics, aimed at studying the problems of people with disability, the effectiveness and efficiency of individual measures of their (re-) integration; behaviour of society and individual groups of the population towards people with disability, the opportunities for participation of certain groups of people with disability in such types of work which were previously unavailable to them.

Key words: people with disability; stigma; discrimination; society; integration; social life; labour activity.

\section{INTRODUCTION / ВСТУП}

The problem of the people's integration with disability into public life has been existing throughout human existence. At the same time, despite the significance of this problem, it is no secret that the level of this problem's solution remains low, even in developed countries. WHO estimates that over one billion people, about $15 \%$ of the world's population, have one form of disability and only about $5 \%$ of them have congenital disability. A quarter of them are young people, $80 \%$ of whom live in the developing countries. People with disability form the largest minority in the world, but unlike many other minorities, it always has an open membership: each of us can become its member at any time due to an accident, illness or ageing.

Thus, disability is a part of human existence. It is considered that the disability, in the vast majority of cases, is a consequence of social, economic or political factors, an accident or armed conflict. Currently, there can be more factors, which contribute to the incident increasing of disability cases, including pollution, HIV/AIDS and drug addiction.

Disability has been stopped to examine as only medical problem, and it is increasingly understood as limiting the social and psychological functioning of the individual on the background of a number of significant institutions such as education, culture, politics, family, etc. The attitude to the disabled people have 
always been ambiguous and has changed throughout the history of the world. It was not until the twentieth century that ideas of tolerance and equal opportunity began to emerge in the world. However, in today's social reality, there are different stereotypes about people with disability.

Now it is difficult to say when the term «disabled» was widely used, literally it means from Latin «invalid», «non-existent». For many years, this term has been using in the international linguistic space, including the regulatory sources, but its usage is often considered unethical and even discriminatory. At the same time, it should be noted that the term «disabled» has replaced many other, truly rough formulation. For example, people with physical defects were called «poor» or «crippled» in Rus, for describing such people in Spain it was used the term «minusválidos» (translated from Spanish as «inferior»). In Germany, people with disability were marked as the word «Krüppel» (translated from German as «cripple»), later it was replaced by the polite word «Vehinderte» (translated from German «disabled person»). The rough word «Cripple» in the English language space was also replaced by the word «Disabled person».

There is no current definition of disability, although there have been made many different attempts to derive the single meaning of this word. The World Health Organization (WHO) takes into account the social aspects of disability and does not consider disability just how a phenomenon of «medical» or «biological» dysfunction in its International Classification of Functioning, Disability and Health (ICF). Disability is any limitation or absence (due to the defect) of the ability to perform the activities in the order or within the limits considered normal for a person [1].

New research suggests that even with improvements, most people with disability remain socially impressionable; they have no full social life and have difficulty finding employment, or cannot go beyond specialized enterprises and be stigmatized by society [2], [3]. At the same time, this problem and its causes are much more complicated in practice and not limited to physical obstacles. Other factors further complicate it.

Today, for Ukraine the problem of stigmatizing people with certain physical health disorders is actual. Firstly, the implementation of social programs, actions and initiatives direct to the comprehensive rehabilitation of people with certain physical health disorders and realization their potential, despite all other factors; it is significantly slowed down by the fact that there is a set of persistent negative stereotypes in Ukrainian society regarding such people.

The concept of stigma was originated in Ancient Greece and was applied to the people who have any physical weakness because of punishment or branding. 
Thus, the stigma testified to the owner's belonging to certain, as a rule, marginal groups (slaves, criminals, traitors, etc.) [4]. The modern interpretation of stigma is not differ from initial its original meaning. It is defined as a «label» attached to the basic social status of the individual.

The theory of social Darwinism and the associated Eugenics movement proclaimed the idea that the human gene pool could be improved by human intervention, and they played a major role in labelling people with disability as «worse». Physical disorders lead to limitation of health, form the conception of the «peculiarity» of the person who has them. In this case, disability acts as a kind of «body stigma».

Analysis of recent research and publications / Аналіз останніх досліджень та публікацій Many scientific papers are discussed the problem of stigmatization and limitation of human rights related to the national questions, religion, sexual orientation and disability. The analysis of recent research of the stereotyping of social thinking and the study of different types of social stereotypes were engaged in such Ukrainian and Russian scientists as I. Pavlov, M. Holovatyi, A. Liebiediev-Liubimov, L. Lieontieva, T. Madrzhytskyi, S. Matvieiev, A. Derkach, V. Ahieiev, V. Yadov, A. Pevzner, Yu. Kryzhanska and others. Among foreign authors, the following representatives of social psychology and sociology investigated this question: U. Lipman, D. Katts, P. Breili, R. Nisbet, M. Ros, D. Hamilton, N. Kentor, K. Makoli and others.

Such foreign researchers were engaged in the study of stigma phenomenon and the study of its various types, as I. Hofman, K. Plamer, V. Lipp and others. Among native, Russian and Belarusian researchers this topic was researched by the following authors: T. Semyhina, T. Vorotyntseva, Ye. Novikov, A. Aleksandrov, S. Kostiuchenko and others.

Unfortunately, in Ukraine the studying of the problems of people's stigmatization with disability as factors that prevent their integration / reintegration and the implementation of effective measures to overcome these obstacles and improve the lives of disabled people leaves much to be desired. At the same time, the modern European integration processes are forcing Ukraine to revise the existing approaches and opportunities to improve this situation.

\section{AIM AND TASKS / МETA TA ЗАВДАННЯ}

\section{Purpose of the article / мema cmammi}

The purpose of the article is to study the problem of stigmatization of disabled people as an obstacle to their integration into a full value social life, including professional realization. 
Вісник післядипломної освіти. Випуск 9(38) «Серія «Соціальні та поведінкові науки» https://doi.org/10.32405/2522-9931

\section{tasks: \\ According to the purpose of the article, it is put up the following}

- to realize the theoretical analysis of the scientific literature and to determine the main approaches to the study of the stigmatization's problem of people with disability;

- to analyze the main psychological barriers that occur in people with disability as a result of stigma;

- to consider the possible ways of eliminating the problem of discrimination and stigmatization of people with special needs in the process of integrating them into the socially active population.

Most of today's human rights problems, which concern to disability, are related to stigma and discrimination. Disabled people have rights to the same rights as non-disabled people, who can be discriminated directly and indirectly and excluded from almost every sphere of life.

\section{THE THEORETICAL BACKGROUNDS / TEOPETИЧHI ОСНОВИ ДОСЛІДЖЕННЯ}

Stigmatization of people with disability as a social group is becoming increasingly significant socio-cultural phenomenon. At the same time, the mechanisms of stigmatization are also manifested at the level of selfidentification. In such cases, it is customary to talk about self-stigma. Therefore, E. Lemert notes that the personality, in the process of stigma influence, is gradually used in the proposed image [5]. Moreover, the behaviour and purposefulness of the stigmatized individual are carried out in accordance with the assigned social role. Thus, a person who has partially lost his or her ability to work, in the process of exposure to the label «helpless patient», can completely refuse from the energetic activity over time, even if the necessary capacity is retained or restored because of successful rehabilitation. In addition, the stigma of disability can develop in a person such personal qualities as infantile, weak will, abstinence. It is not important anymore, as others perceive this individual as a typical representative of society or not in self-stigmatization. If an individual identifies himself/herself as a member of a particular community, his/her attitudes and behaviour will be marked accordingly.

Depending on whether the stigma is visualized (for example, when the disease is expressed outside and it cannot be hidden) or latent, which is known only to its owner, for example, in the case of inner diseases, the individual may respond to it differently. In the first case, the individual is the carrier of discredited stigma, in the second case - the discreditable. This creates an internal personal dramatic problem of control over tension due to the feeling of uncharacteristic. 
People with disability may have at least three stigma strategies: the acceptance which may be expressed in the passive maintenance to the attributed image; in some cases, speculation of illness with the treatment of privilege of attention and sympathy; resistance, which is realized through compensatory behaviour and oppose to the typical image, it is transmitted outside through positive or negative forms of deviation.

In addition, it should take into consideration that if the attitude to the people with disability has been changing during the history, the content of disability stigmas has changed accordingly [6].

\section{RESEARCH METHODS / МЕTОДИ ДОСЛІДЖЕННЯ}

The theoretical methods of research were used to solve the tasks and to achieve the goal of the work: the theoretical analysis of theoretical and methodological, scientific and methodological literature to compare different views of the problem; induction, deduction; generalization and systematization in order to separate the main approaches for studying of the stigmatization's problem of people with disability as obstacles to their integration into a full value social life, including professional realization.

\section{RESEARCH RESULTS / РЕЗУЛЬТАТИ ДОСЛІДЖЕННЯ}

The problem of stigmatization of people with disability remains acute both in Ukraine and in other countries of the world. Particularly painful this question is for those with disability who strive for full value working life and professional realization.

Discrimination can be manifested in various forms when hiring - refusal of work, offer of work of lower qualification level, offer of worse conditions of payment. In addition, in the process of work, the discrimination against a person with a disability can manifest on a daily attitude towards that person, blocking career opportunities without objective reasons, ignoring that person's success and her contribution to the joint activity. Stigmatization is quite close to discrimination. In addition, the causes of the problem are not only physical defects of people with disability. First, there is a high level of corruption in Ukraine and there are people who have made a disability for money. Certainly, after that, the society will be sceptical and suspicious for all people with disability, who do not have the physical manifestations of disability. For example, if a person does not have an arm or a leg, this defect is obvious, whereas those who, for example, have serious cardiovascular disease, such people may be accused of «faked» disability.

On the other hand, as some studies [6] show, the imperfection of the system leads to the fact that people with disability stop to seek changes in life, 
Вісник післядипломної освіти. Випуск 9(38) «Серія «Соціальні та поведінкові науки» https://doi.org/10.32405/2522-9931

lose the interest to the normal employment, become accustomed to being concerned about the state and gradually begin to occupy the passive position in their life. This situation leads to the fact, that people with disability are poorly integrated into the society and become subject to stigma. They are despised, considered a burden to society, lazy and so on [6], [7]. This situation particularly complicates the lives of those people who, the physical obstacles, want to find a full-time job and have a full social and working life.

For some people with disability, entry into the open labour market is very difficult due to physical reasons, while other people with disability have fewer restrictions and can compete with ordinary candidates for employment in nonspecialized enterprises with dignity. However, they are prevented by psychological barriers or lack of education or information.

The experience of psychologists shows that people with special needs often touch with the specific problems in different spheres of life, such as education, employment, community service, family relations, life and leisure, communication, etc.

People with disability belong to different groups according to the level of complexity of their physical or psychophysical state, place of residence, social status. Severe chronic somatic disease significantly changes the completely socio-psychological situation of human development. It significantly affects the level of her mental capacity in the implementation of the activity; leads to a limitation of the circle of contacts with people, who surround them, often for objective or subjective reasons, leads to a restriction of her activity as a whole, that is, changes the objective place that occupies a person in life and, as a consequence, his or her inner position in all circumstances of life [8].

The defects of people with disability significantly complicate their contacts with the environment, limit their participation in public life, and adversely affect their personal development: cause feelings of anxiety, self-doubt, and lead to the formation of inferiority complex, self-centered and asocial moods.

Two major groups of barriers are physical and psychological, that prevent people with disability from having a fulfilling social life, including professional realization. Typically, the most attention is focused on the first group, which is directly related to the physical limitations that a disabled person has. At the same time, the psychological barriers are equally important. The sources of these barriers can be people with disability and all other people.

Firstly, a person with a disability can seek more isolated life from society. These people often close up in their world and have a very narrow circle of communication, which includes family members, doctors, possibly a few friends and the same disability people. The first reason for this lifestyle may be the limitation of physical activity and the lack of adequate infrastructure, which 
makes a person as a prisoner of his own apartment. In addition, a person may lose faith in himself and others, and refuse the opportunity to realize himself in society.

Secondly, the stigmatization remains widespread and, as a consequence, other people's unwillingness to accept people with disability into their environment.

The main psychological barriers for people with disability due to stigma are:

1) The communication barrier is a disorder of communication, one of the most complex social problems for children and young people with disability, which is the result of emotional protective self-isolation. The communicative barrier creates the motivational, ethical and emotional difficulties [9]. There are motivational difficulties: excessive motivation (for example, «I was worried and didn't say anything, I mentioned it»); lack of motivation (I do not want to understand, it is not interesting), etc. There are ethical (moral) difficulties: lack of tact, tolerance; discretion, boldness; gossip, rumors, deceit, meanness, dishonesty; envy, animus, etc. There are emotional difficulties: untidy, outrageous appearance; bold postures, gestures, manners, habits, etc.; brutal tone, tone of voice, etc.;

2) The barrier of business communication raises problems, which are related to the characteristics of healthy people and people with functional health limitations, which arise when they pay attention to those aspects of the person that he does not realize or wants to hide, in our case these are physical defects. Some authors, when they consider the problem of social integration of people with poor physical health, even suggest the introducing of the concept of «valeological equality» to denote the perception of a person with health disorders as equal and such who has a different worldview, a different lifestyle and special needs [8];

3) The emotional barrier consists of people's emotional reactions and it is two-way. That is, on the one hand, healthy people can show curiosity, mockery, inconvenience, guilt, hyper custody, fear; on the other hand, people with special needs can wait for self-pity, hyper custody, they may blame someone for their defect, seek isolation, etc. [9]. A person with a disability may have a negative experience in dealing with so-called "normal" people through stigma, neglect, misunderstanding, insults [7].

The problem of discrimination and stigmatization of people with disability remains acute both in Ukraine and in other countries of the world [2]. However, it is obvious that the formal prohibition of discrimination at the state level does not eliminate this problem. Particularly painful is the question for those people with disability who see a fulfilling working life and professional realization. 
To removal the problem of discrimination and stigmatization, the scientists suggest work in two ways: to take action with those who are stigmatized and discriminated and with those who stigmatizes and discriminates, which requires different methods of solving the problem [2]. Working with people with disability should help them to take an active life position, and this should be supported by appropriate rehabilitation, training, counselling and infrastructure arrangements. In turn, the working with others should be directed to developing a conscious vision of the problems of people with disability, understanding and tolerance.

\section{CONCLUSIONS AND PROSPECTS FOR FURTHER RESEARCH / ВИСНОВКИ ТА ПЕРСПЕКТИВИ ПОДАЛЬШИХ ДОСЛІДЖЕНЬ}

Finding the ways to solve the problem of social and psychological integration of people with disability it should begin with depth analysis of the barriers that stand in the way of such people and overcoming the resistance and stigmatization of society. In many cases, the main barrier, such as physical limitation of the person, cannot be eliminated. However, the existing approaches allow to overcome or reduce both physical and psychological, communication, information and educational barriers. It is also important is a comprehensive approach and the use of different methods at the same time to achieve a faster and more efficient result.

\section{Prospects for further research / Перспективи подальших досліджень}

Thus, the prospect of further research one of the important actions in the medium and long perspectives is to carry out the scientific research on various topics, aimed at studying the problems of people with disability, the effectiveness and efficiency of individual measures of their (re-) integration, behaviour of society and individual groups of the population towards people with disability, the opportunities for participation of certain groups of people with disability in such types of work which were previously unavailable to them. Certainly, such research is being conducted, but unfortunately, Ukraine lacks the financial and material resources to carry out complex, sometimes long-lasting, high-quality research.

\section{REFERENCES (TRANSLATED AND TRANSLITERATED) / СПИСOК ВИКОРИСТАНИХ ДЖЕРЕЛ}

[1] World Health Organization «Disability and health» [Electronic resource]. Available: www.who.int/mediacentre/factsheets/fs352/en/index.html 
[2] M. Ameri, L. Schur, M. Adya, S. Bentley, P. McKay, D. Kruse, «The disability employment puzzles: a field experiment on employer hiring behavior», Labor and Employment Relations Association conference. 2015, pp. 1-70.

[3] Н.А. Бєлоносова, «Стигматизація осіб з порушеннями фізичного здоров'я на ринку праці», Ринок праці та зайнятість населення, № 2, c. 38-42, 2011.

[4] E. Goffman, Stigma: notes on the management of spoiled identity. Simon \& Schuster Adult Publishing Group. 1986, 168 p.

[5] E. Lemert, Social Pathology: A Systematic Approach to the Theory of Sociopathic. Behavior. NY: Mc-Graw-Hill. 1951, 459 p.

[6] Е. В. Воеводина, «Инвалид» как социальная стигма и пространство для дискуссий», Человек. Общество. Инклюзия, № 4(20), с. 10-15, 2014.

[7] П. С. Алпатова, Т. С. Зуб, «Людина 3 обмеженими фізичними можливостями в міському середовищі», Український соціум, № 1, с. 716, 2006.

[8] С. Богданов, Б. Мойса, «Пропозиції до політики щодо працевлаштування осіб з інвалідністю». [Електронний ресурс]. Лабораторія законодавчих ініціатив, 2017.

Доступно: http://parlament.org.ua/wp-

content/uploads/2017/09/DisabledPolicy.pdf

[9] О.М. Дікова-Фаворська, «Адаптаційні можливості освіти осіб 3 інвалідністю». [Електронний ресурс]. Соціальні технології: актуальні проблеми теорії та практики: міжвузів. зб. наук. праць, № 42, 2009. Доступно : http://www.nbuv.gov.ua/portal/Soc_Gum/Staptp/2009_42/fi les/42_07Dikova 202 Favorska.pdf

\title{
СТИГМАТИЗАЦІЯ ОСІБ ІЗ ІНВАЛІДНІСТЮ ЯК ПСИХОЛОГІЧНИЙ БАР'ЄР НА ШЛЯХУ ІНТЕГРАЦІЇ ДО СУСПІЛЬНОГО ЖИТТЯ
}

\author{
Оверчук Вікторія Анатоліївна, \\ кандидат психологічних наук, доцент, \\ доцент кафедри «Психологія» \\ Донецького національного університету \\ імені Василя Стуса. \\ Вінниця, Україна. \\ ORCID iD: https://orcid.org/0000-0002-7744-9346 \\ vik.over030506@gmail.com
}

Анотація. Стаття присвячена проблемі стигматизації людей 3 певними порушеннями фізичного здоров'я. Реалізація соціальних програм, заходів та ініціатив, спрямованих на комплексну 
реабілітацію людей з певними порушеннями фізичного здоров'я та реалізацію ними потенціалу, попри всі інші чинники, істотно гальмується тим, що на побутовому рівні в українському суспільстві існує комплекс стійких негативних стереотипів відносно таких людей. Стигматизація осіб з інвалідністю як соціальної групи стає все більш значимим соціокультурним явищем. У той же час механізми стигматизації проявляються і на рівні самоідентифікації. У осіб з інвалідністю можливе формування, щонайменше, трьох стратегій щодо стигми: прийняття, спекуляція хворобою, опір. Особливо болючим питання стигматизації $є$ для тих осіб з інвалідністю, які прагнуть повноцінного трудового життя і професійної реалізації. Проблема дискримінації та стигматизації осіб 3 інвалідністю залишається гострою як в Україні, так і в інших країнах світу. При цьому очевидним $\epsilon$ те, що формальна заборона дискримінації на державному рівні не усуває цю проблему повністю. Особливо болючим це питання $є$ для тих осіб з інвалідністю, які прагнуть повноцінного трудового життя і професійної реалізації.

Для усунення проблеми дискримінації та стигматизації необхідно працювати за двома напрямами: проводити заходи з тими кого стигматизують і дискримінують і 3 тими, хто стигматизує та дискримінує, що потребує різних методів вирішення проблеми. Робота з особами з інвалідністю має допомогти цим людям зайняти активну життєву позицію i це все потрібно підтримувати відповідними реабілітаційними, навчальними, консультаційними заходами та облаштуванням інфраструктури. У свою чергу, робота 3 іншими людьми повинна бути направлена на розвиток свідомого бачення проблем осіб з інвалідністю, розуміння і толерантності. Отже, одним із важливих заходів в середньо та довгостроковій перспективі $€$ проведення наукових досліджень різної тематики, направлених на вивчення проблем осіб з інвалідністю, ефективності та результативності окремих заходів їх (ре-)інтеграції, поведінки суспільства та окремих груп населення по відношенню до осіб 3 інвалідністю, можливостей участі окремих груп осіб з інвалідністю в таких видах трудової діяльності, які раніше були для них недоступні.

Ключові слова: особи з інвалідністю; стигматизація; дискримінація; суспільство; інтеграція; суспільне життя; трудова діяльність. 


\title{
СТИГМАТИЗАЦИЯ ЛИЦ С ИНВАЛИДНОСТЬЮ КАК ПСИХОЛОГИЧЕСКИЙ БАРЬЕР НА ПУТИ ИНТЕГРАЦИИ К ОБЩЕСТВЕННОЙ ЖИЗНИ
}

\author{
Оверчук Виктория Анатольевна, \\ кандидат психологических наук, доцент, \\ доцент кафедры «Психология» \\ Донецкого национального университета \\ имени Василия Стуса. \\ Винница, Украина. \\ ORCID iD: https://orcid.org/0000-0002-7744-9346 \\ vik.over030506@gmail.com
}

Аннотация. Статья посвящена проблеме стигматизации людей с определенными нарушениями физического здоровья. Реализация социальных программ, мероприятий и инициатив, направленных на комплексную реабилитацию людей с определенными нарушениями физического здоровья и реализацию ими потенциала, несмотря на все другие факторы, существенно тормозится тем, что на бытовом уровне в украинском обществе существует комплекс устойчивых негативных стереотипов по отношению к таким людям. Стигматизация лиц с инвалидностью как социальной группы становится все более значимым социокультурным явлением. В то же время механизмы стигматизации проявляются и на уровне самоидентификации. У лиц с инвалидностью возможно формирование как минимум трех стратегий по отношению к стигмам: принятие, спекуляция болезнью, сопротивление. Особенно болезненным вопрос стигматизации является для лиц с инвалидностью, которые стремятся к полноценной трудовой жизни и профессиональной реализации.

Проблема дискриминации и стигматизации лиц с инвалидностью остается острой как в Украине, так и в других странах мира. При этом очевидно, что формальный запрет дискриминации на государственном уровне не устраняет эту проблему полностью. Особенно болезненным этот вопрос является для лиц с инвалидностью, которые стремятся к полноценной трудовой жизни и профессиональной реализации.

Для устранения проблемы дискриминации и стигматизации необходимо работать по двум направлениям: проводить мероприятия с теми кого стигматизирует и дискриминируют и с теми, кто стигматизирует и дискриминирует, что требует различных методов решения проблемы. Работа с лицами с инвалидностью 
должно помочь этим людям занять активную жизненную позицию и это все нужно поддерживать соответствующими реабилитационными, учебными, консультационными мероприятиями и обустройством инфраструктуры. В свою очередь, работа с обществом должна быть направлена на развитие сознательного видения проблем лиц с инвалидностью, понимания и толерантности.

Таким образом, одним из важных мероприятий в средне и долгосрочной перспективе является проведение научных исследований различной тематики, направленных на изучение проблем лиц с инвалидностью, эффективности и результативности отдельных мероприятий по их (ре)интеграции, поведения общества и отдельных групп населения по отношению к лицам с инвалидностью, возможностей участия отдельных групп лиц с инвалидностью в таких видах трудовой деятельности, которые ранее были для них недоступны.

Ключевые слова: лица с инвалидностью; стигматизация; дискриминация; общество, интеграция; общественная жизнь; трудовая деятельность.

\section{REFERENCES (TRANSLATED AND TRANSLITERATED)}

[1] World Health Organization «Disability and health» [Electronic resource]. Available: www.who.int/mediacentre/factsheets/fs352/en/index.html

[2] M. Ameri, L. Schur, M. Adya, S. Bentley, P. McKay, D. Kruse, «The disability employment puzzles: a field experiment on employer hiring behavior», Labor and Employment Relations Association conference. 2015, pp. 1-70.

[3] N. A. Bielonosova, «Styhmatyzatsiia osib z porushenniamy fizychnoho zdorovia na rynku pratsi», Rynok pratsi ta zainiatist naselennia, № 2, s. 38-42, 2011.

[4] E. Goffman, Stigma: notes on the management of spoiled identity. Simon \& Schuster Adult Publishing Group. 1986, 168 p.

[5] E. Lemert, Social Pathology: A Systematic Approach to the Theory of Sociopathic. Behavior. NY: Mc-Graw-Hill. 1951, 459 p.

[6] E. V. Voevodina, «Invalid» kak social'naya stigma i prostranstvo dlya diskussij», CHelovek. Obshchestvo. Inklyuziya, № 4(20), s. 10-15, 2014.

[7] P.S. Alpatova, T.S. Zub, «Liudyna $z$ obmezhenymy fizychnymy mozhlyvostiamy v miskomu seredovyshchi», Ukrainskyi sotsium, № 1, s. 7-16, 2006. 
[8] С. Богданов, Б. Мойса, «Пропозиції до політики щодо працевлаштування осіб 3 інвалідністю». [Електронний ресурс]. Лабораторія законодавчих ініціатив, 2017. Доступно: http://parlament.org.ua/wp-content/uploads/2017/09/DisabledPolicy.pdf

[9] О. М. Дікова-Фаворська, «Адаптаційні можливості освіти осіб 3 інвалідністю». [Електронний ресурс]. Соціальні технології: актуальні проблеми теорії та практики: міжвузів. зб. наук. праць, № 42, 2009. Доступно : http://www.nbuv.gov.ua/portal/Soc_Gum/Staptp/2009_42/fi les/42_07Dikova 202 Favorska.pdf 